\title{
A REVIEW ON DRUG APPROVAL PROCESS FOR US, EUROPE AND INDIA
}

\author{
Available online at www.ijdra.com \\ REVIEW ARTICLE \\ ${ }^{1}$ Prajapati Vishal*, ${ }^{1}$ Goswami Rahulgiri, ${ }^{1}$ Makvana Pratik, ${ }^{2}$ Badjatya Jitendra Kumar \\ ${ }^{1}$ L.J. Institute of Pharmacy, S.G. Highway, Ahmedabad, Gujarat, India. \\ ${ }^{2}$ Montajat Pharmaceuticals Co. Ltd., Dammam, KSA \\ *Corresponding Author's E-mail:vp46556@gmail.com
}

\begin{abstract}
:
Developing a new drug requires great amount of research work in chemistry, manufacturing, controls, preclinical science and clinical trials. Drug reviewers in regulatory agencies around the world bear the responsibility of evaluating whether the research data support the safety, effectiveness and quality control of a new drug product to serve the public health. Every country has its own regulatory authority, which is responsible to enforce the rules and regulations and issue the guidelines to regulate the marketing of the drugs. This article focuses on drug approval process in different countries like USA, Europe and India.
\end{abstract}

Kevwords: MAA, USFDA. Drug approval, Clinical trial.

\section{Introduction:}

Currently different countries have to follow different regulatory requirements for approval of new drug. For marketing authorization application (MAA) a single regulatory approach is applicable to various countries is almost a difficult task. Therefore it is necessary to have knowledge about regulatory requirement for MAA of each country. The basic regulation can be understood from Fig 2 .

\section{Drug approval in United States (1-3):}

The United States has perhaps the world's most stringent standards for approving new drugs. Drug approval standards in the United States are considered by many to be the most demanding in the world.

\section{Investigational New Drug (IND) Application}

It's an application filed to the FDA in order to start clinical trials in humans if the drug was found to be safe from the reports of Preclinical trials. A firm or institution, called a Sponsor, is responsible for submitting the IND application. A pre - IND meeting can be arranged with the FDA to discuss a number of issues:
- The design of animal research, which is required to lend support to the clinical studies

- The intended protocol for conducting the clinical Trial

- The chemistry, manufacturing, and control of the investigational drug

Such a meeting will help the Sponsor to organize animal research, gather data, and design the clinical protocol based on suggestions by the FDA. A clear flow chart of the IND process is illustrated in figure 1.

\section{New Drug Application (NDA)}

If clinical studies confirm that a new drug is relatively safe and effective, and will not pose unreasonable risks to patients, the manufacturer files a New Drug Application (NDA), the actual request to manufacture and sell the drug in the United States. The process of NDA has been illustrated in figure 3 .

\section{Abbreviated New Drug Application (ANDA)}

It's an application made for approval of Generic Drugs. The sponsor is not required to reproduce the clinical studies that were done 
for the original, brand name product. Instead, generic drug manufacturers must demonstrate that their product is the same as, and bioequivalent to, a previously approved brand name product. The process of ANDA has been illustrated in figure 4.

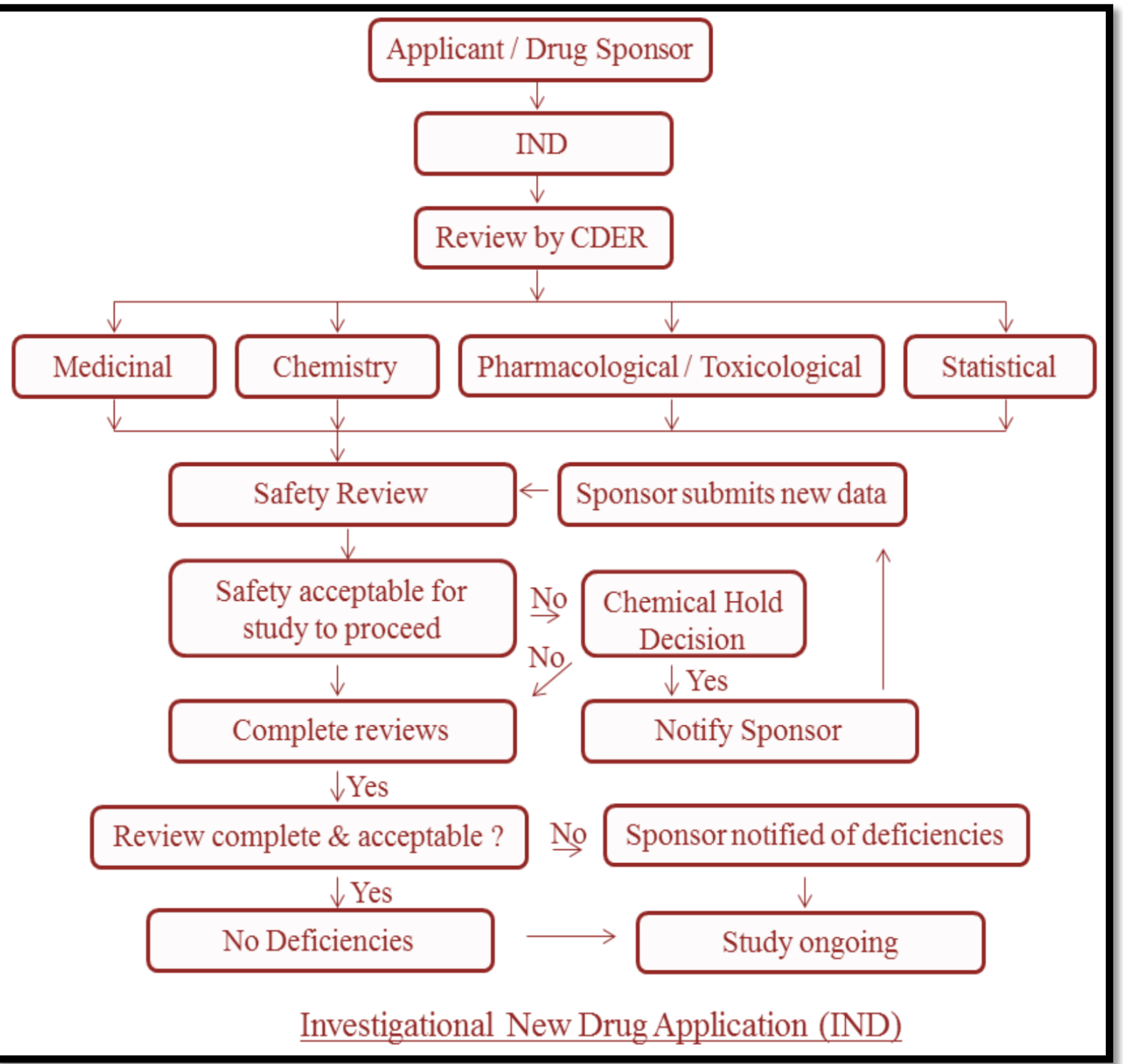

Figure 1: Flow chart of Investigational New Drug Application

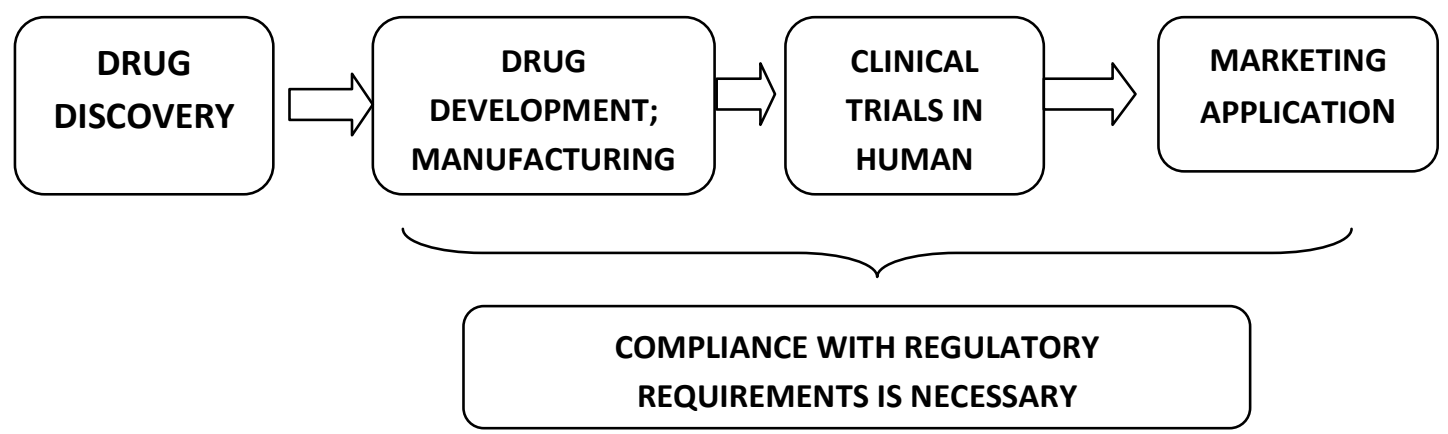

Figure 2: The Basic Regulation 


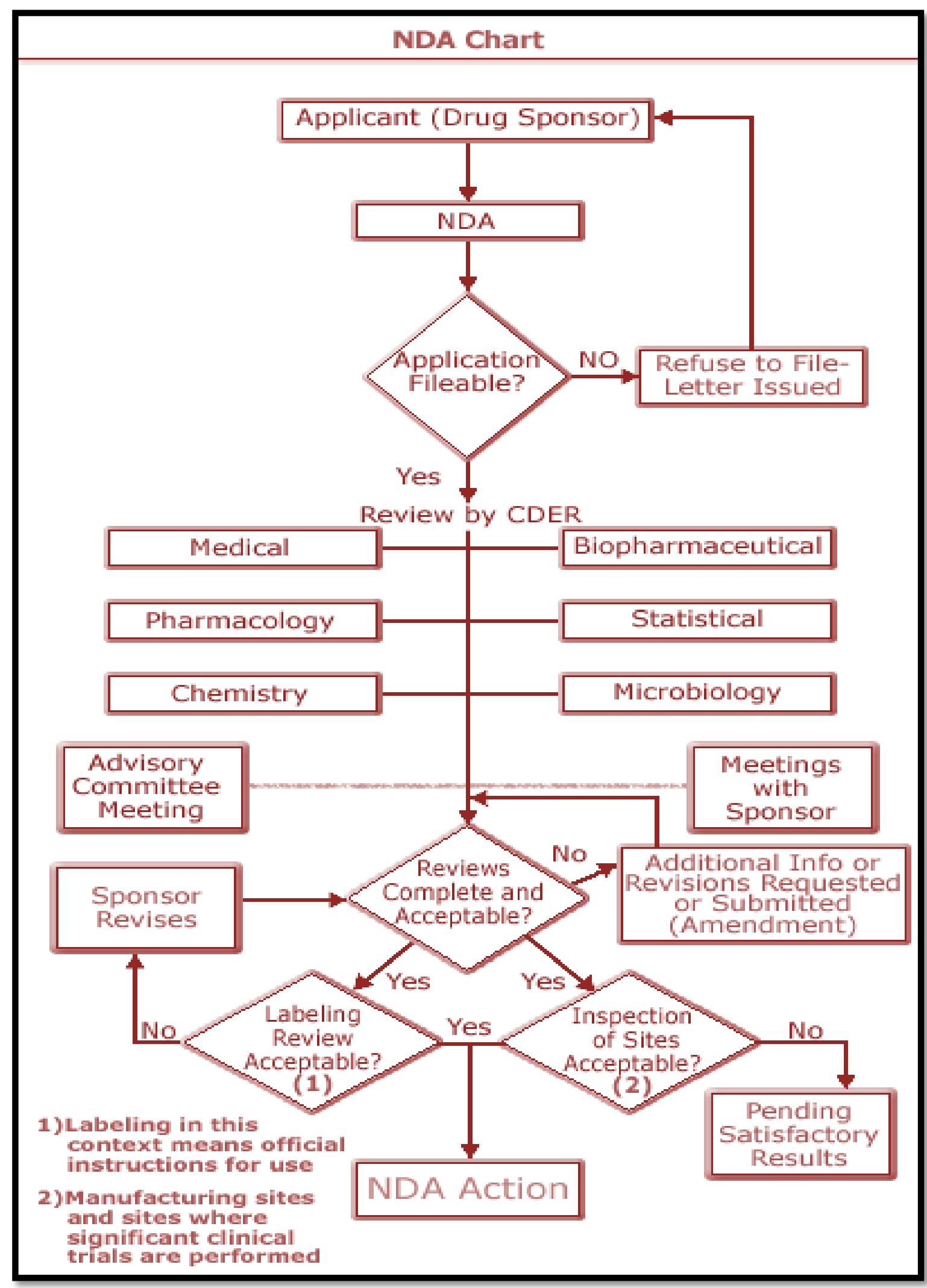

Figure 3: Flow chart of New Drug Application 


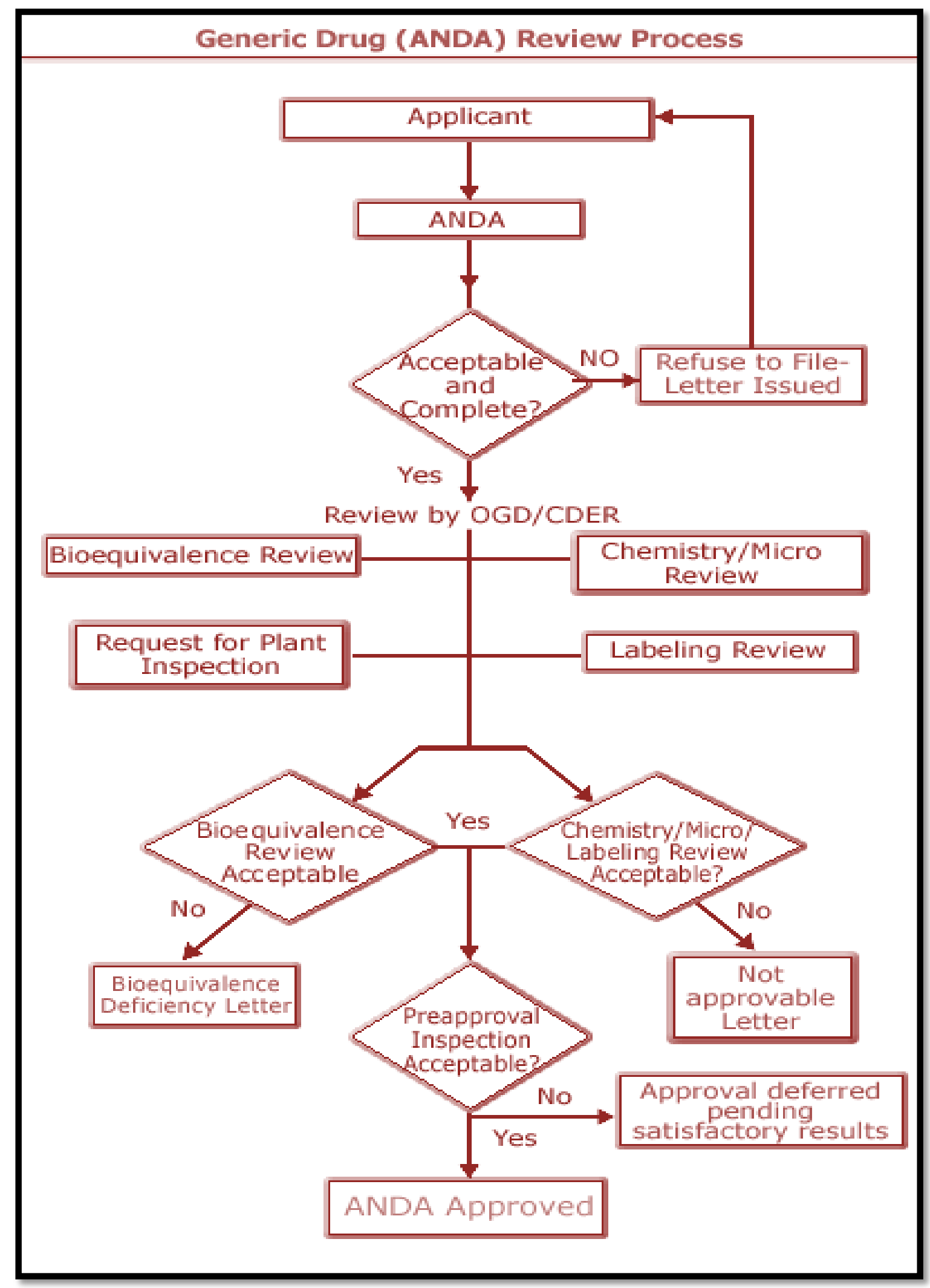

Figure 4: Flow chart of Abbreviated New Drug Application 


\section{Drug approval in Europe (4-6):}

Similar to the US requirements, there are two regulatory steps to go through before a drug is approved to be marketed in the European Union. These two steps are clinical trial application and marketing authorization application. There are 28 member states in the European Union (as of July, 2013); Clinical Trial Applications are approved at the member state level, whereas marketing authorization applications are approved at both the member state and centralized levels.

\section{Centralized procedure}

The centralized procedure is one which allows applicants to obtain a marketing authorization that is valid throughout the EU.

- Results in a single authorization valid in EU, Norway, Iceland and Liechtenstein.

- Application evaluated by an assigned Rapporteur.

- Timeline: EMA opinion issued within 210 days, and submitted to European Commission for final approval.

Centralized process is compulsory for:

- Those medicines which are derived from any biotechnology processes, such as genetic engineering.

- Those medicines which are intended for the treatment of Cancer, HIV/AIDS, diabetes, neurodegenerative disorders or autoimmune diseases and other immune dysfunctions.

- Medicines officially designated 'Orphan medicines' (medicines used for rare diseases).

\section{Mutual Recognition Procedure}

The Mutual Recognition procedure allows applicants to obtain a marketing authorization in the Concerned member states (CMS) other than the Reference member state (RMS), where the drug is previously approved.

- Applicant submits identical dossier to all EU member states in which they want marketing authorization, including required information.
- As soon as one Member State decides to evaluate the medicinal product (at which point it becomes the "RMS"), it notifies this decision to other Member States (which then become the "CMS"), to whom applications have also been submitted.

- RMS issues a report to other states on its own findings.

- Generic industry is the major user of this type of drug approval procedure.

This process may consume a time period of 390 days.

\section{Nationalized Procedure}

The Nationalized procedure is one which allows applicants to obtain a marketing authorization in one member state only.

- In order to obtain a national marketing authorization, an application must be submitted to the competent authority of the Member State.

- New active substances which are not mandatory under Centralized procedure can obtain marketing authorization under this procedure.

- Timeline for this procedure is 210 Days.

\section{Decentralized procedure}

Using this procedure, companies may apply for authorization simultaneously in more than one EU country for products that have not yet been authorized in any EU country and essentially do not fall within the centralized procedure's essential drugs list.

Based on the assessment report which is prepared by the RMS \& any comments made by the CMS, marketing authorization should be granted in accordance with the decision taken by the RMS \& CMS in this decentralized procedure.

- Generally used for those products that has not yet received any authorisation in an EU country.

- Time: 210 days. 


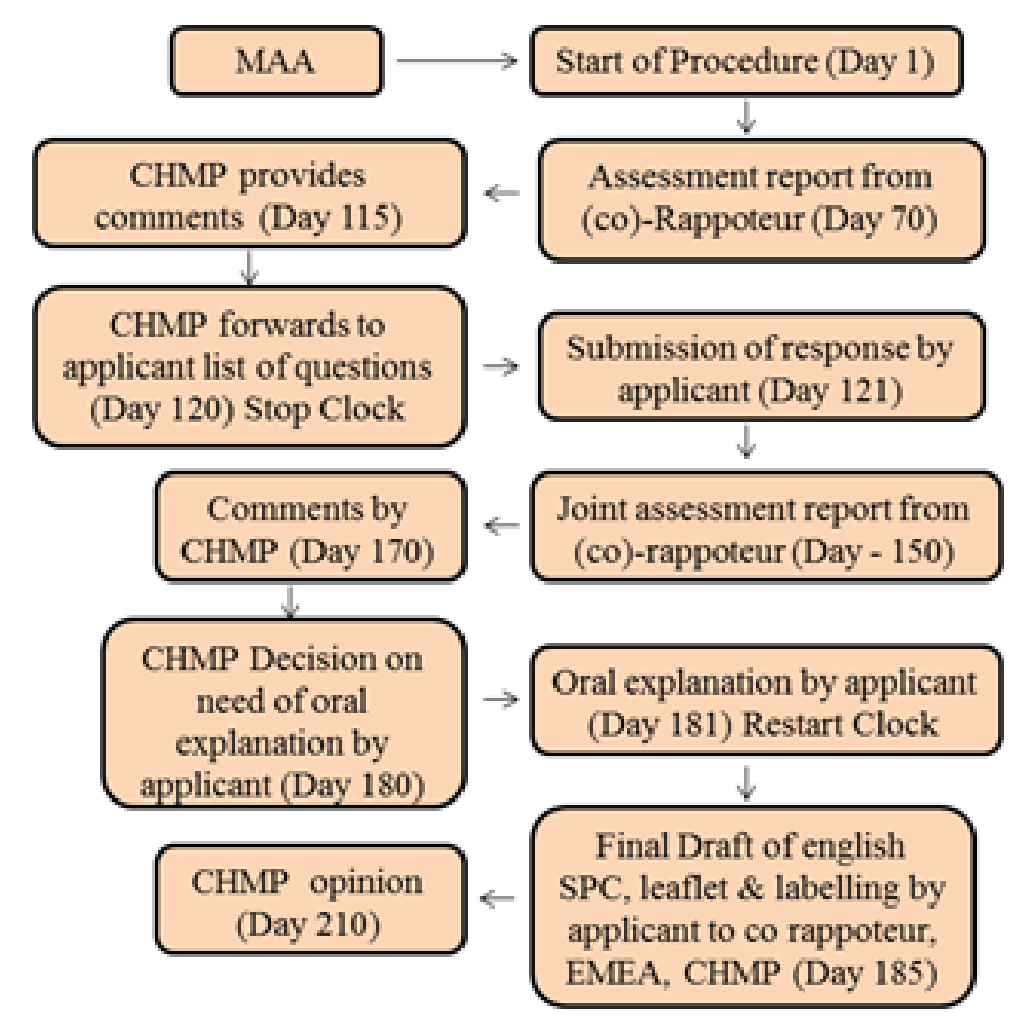

Figure 5: Flow chart of Centralized Procedure

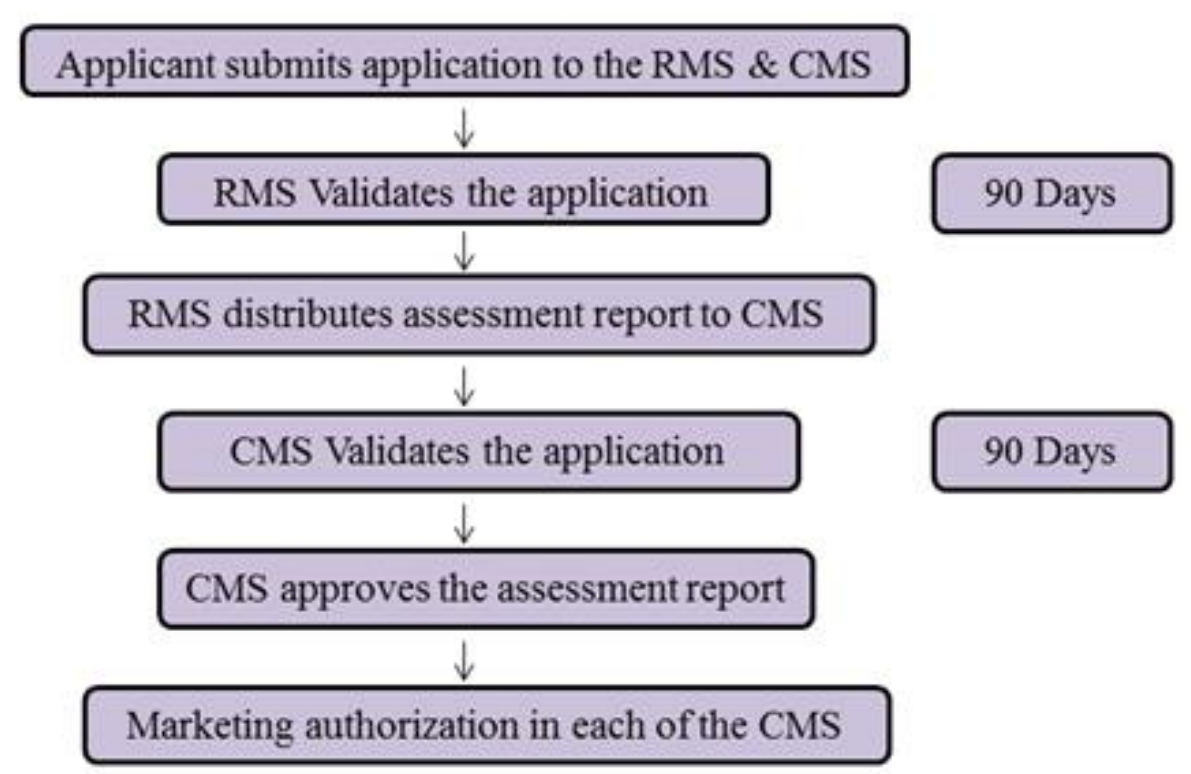

Figure 6: Flow chart of Mutual Recognition Procedure

\section{Approval of New Drug in India (7-10):}

When a company in India wants to manufacture/import a new drug it has to apply to seek permission from the licensing authority (DCGI) by filing in Form 44 also submitting the data as given in Schedule Y of Drugs and Cosmetics Act 1940 and Rules 1945. In order to prove its efficacy and safety in Indian population it has to conduct clinical trials in accordance with the guidelines specified in Schedule $\mathrm{Y}$ and submit the report of such clinical trials in specified format.

But a provision is there in Rule - 122A of Drugs and Cosmetics Act 1940 and Rules 1945 that the licensing authority may waive certain trails if he considers that in the interest of 
public health he may grant permission for import of new drugs basing on the data of the trials done in other countries. Similarly there is another provision in Rule - 122A which says that the clinical trials may be waived in the case of new drugs which are approved and being used for several years in other countries.

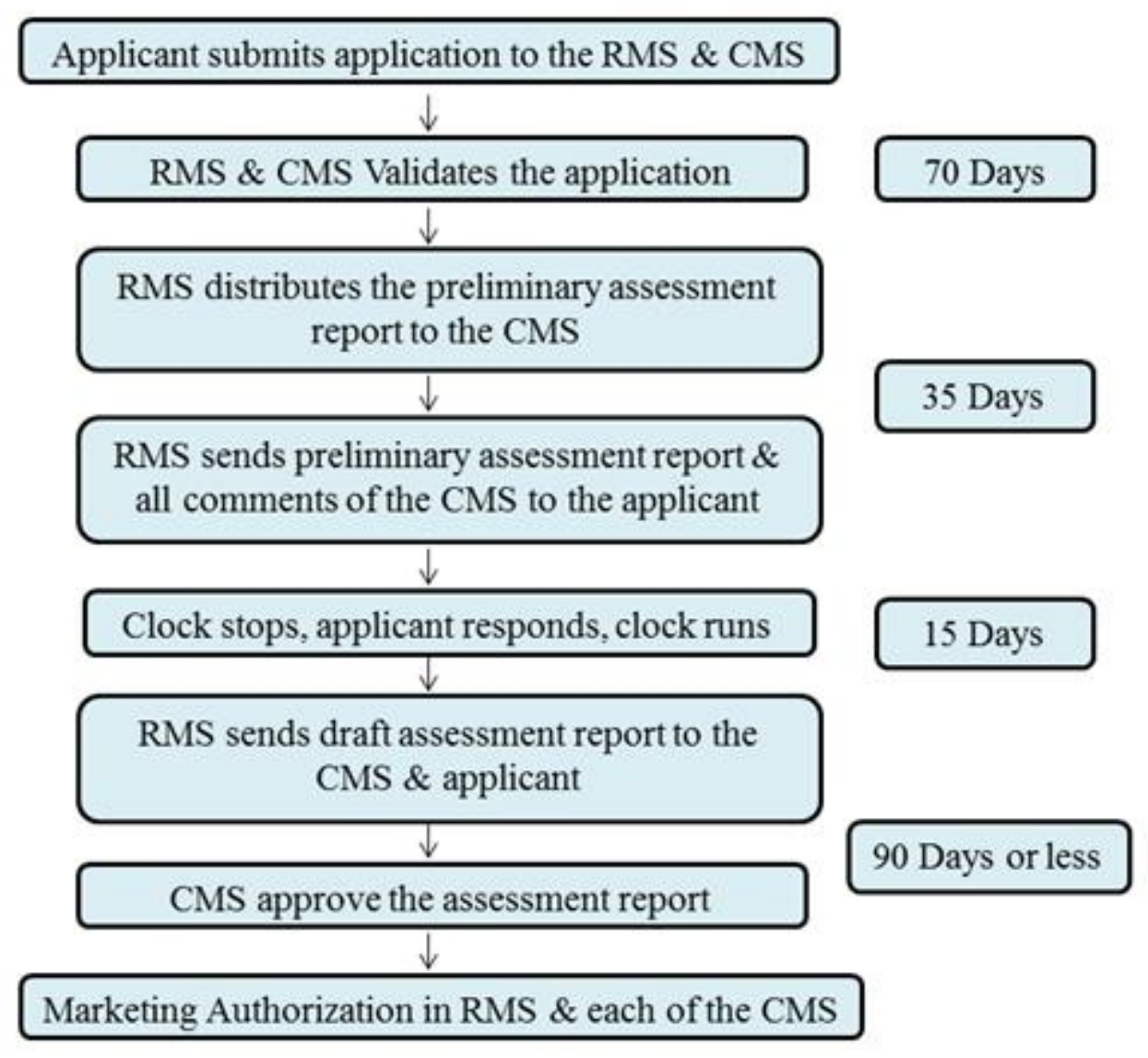

Figure 7: Flow chart of Decentralized Procedure

Section 2.4 (a) of Schedule Y of Drugs and Cosmetics Act 1940 and Rules 1945 says for those drug substances which are discovered in India all phases of clinical trials are required.

Section 2.4 (b) of Schedule Y of Drugs and Cosmetics Act 1940 and Rules 1945 says that for those drug substances which are discovered in countries other than India; the applicant should submit the data available from other countries and the licensing authority may require him to repeat all the studies or permit him to proceed from Phase III clinical trials.

Section 2.8 of Schedule Y of Drugs and Cosmetics Act 1940 and Rules 1945 says that the licensing authority may require pharmacokinetic studies (Bioequivalence studies) first to show that the data generated in Indian population is equal to data generated abroad and then require him to proceed with Phase III trials.

In summary, the exact requirements of Clinical trials may change from case to case and depend on the extent to which licensing authority is satisfied about its safety and efficacy.

The process of approval of new drug in India is a very complicated process, which should meet necessary requirements along with NDA to FDA. The need of the present work is to study and document the requirements for the process of approval of new drug in India with emphasis on clinical trials as per Drugs Control department, Government of India. 


\section{New Drug Application}

NDA is an application submitted to the FDA for permission to market a new drug. To obtain this permission a sponsor submits preclinical and clinical test data to NDA for analyzing the drug information, description of manufacturing procedures.

After NDA received by the agency, it undergoes a technical screening. This evaluation ensures that sufficient data and information have been submitted in each area to justify "filing" the application that is FDA formal review. At the conclusion of FDA review of an NDA, there are 3 possible actions that can send to sponsor:
Not approvable- In this letter list of deficiencies and explain the reason.

Approvable - It means that the drug can be approved but minor deficiencies that can be corrected like-labeling changes and possible request commitment to do post-approval studies.

Approval- It state that the drug is approved.

If the action taken is either an approvable or a not approvable, then FDA provides applicant with an opportunity to meet with agency and discuss the deficiencies.

\section{Drug approval process in India:}

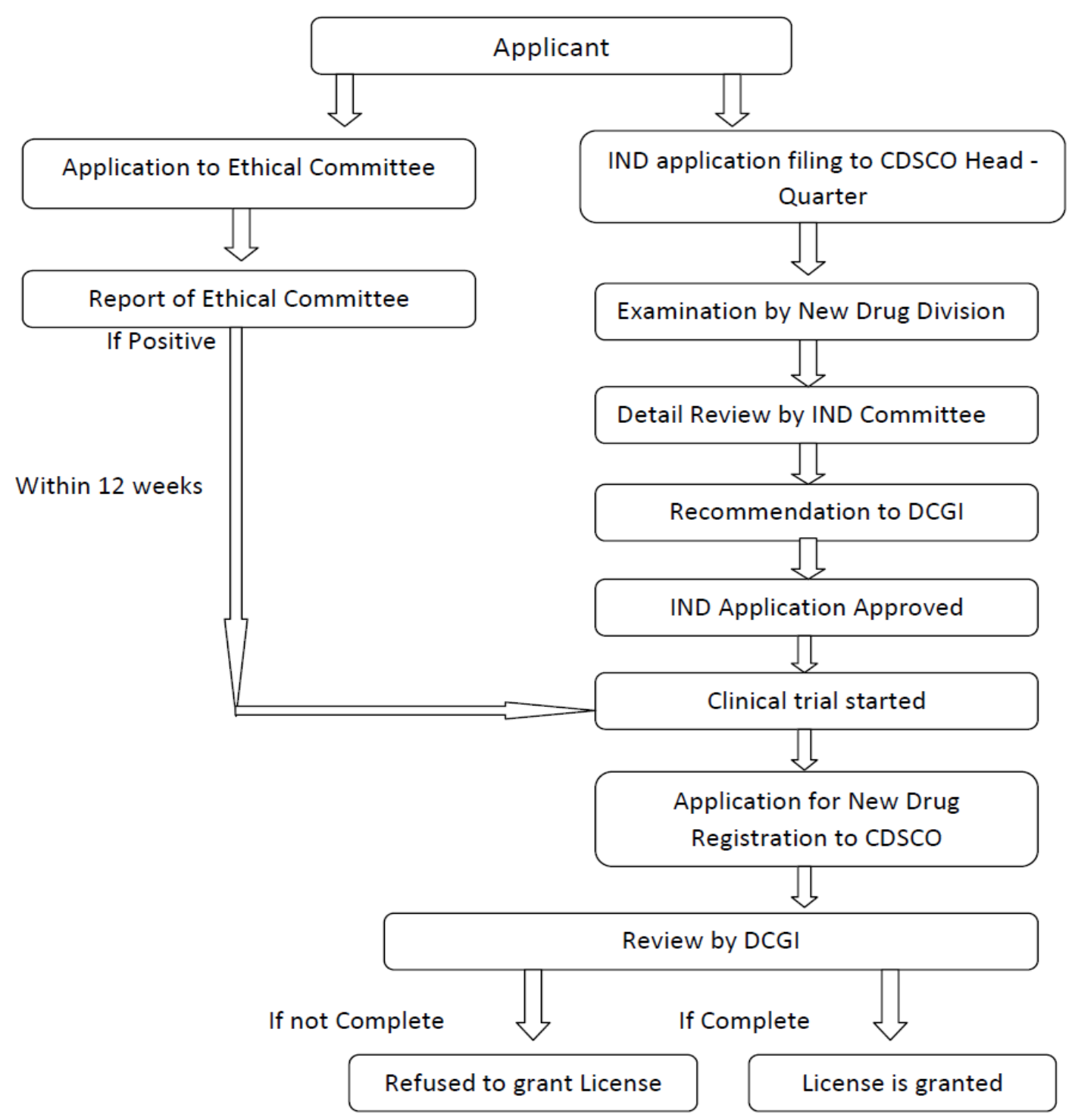

Figure 8: Flow chart of Drug Approval Process in India 


\section{Results \& Discussion:}

Table 1: Principle differences between US, EU \& INDIA

\begin{tabular}{|c|c|c|c|}
\hline Requirements & US & $\mathbf{E U}$ & INDIA \\
\hline Agency & One Agency USFDA & $\begin{array}{l}\text { Multiple Agencies } \\
\text { - } \quad \text { EMEA } \\
\text { - } \text { CHMP } \\
\text { - National Health Agencies }\end{array}$ & One Agency DCGI \\
\hline $\begin{array}{l}\text { Registration } \\
\text { Process }\end{array}$ & $\begin{array}{ll}\text { One } & \text { Registration } \\
\text { Process } & \end{array}$ & $\begin{array}{l}\text { Multiple Registration Process } \\
\text { - Centralized (European } \\
\text { Community) } \\
\text { - } \text { Decentralized (At least } 2 \\
\text { member states) } \\
\text { - Mutual Recognition (At } \\
\text { least } 2 \text { member states) } \\
\text { - National (1 member state) }\end{array}$ & $\begin{array}{l}\text { One Registration } \\
\text { Process }\end{array}$ \\
\hline $\begin{array}{l}\text { TSE/BSE Study } \\
\text { data }\end{array}$ & $\begin{array}{l}\text { TSE/BSE Study data } \\
\text { not required }\end{array}$ & TSE/BSE Study data required & $\begin{array}{ll}\text { TSE/BSE Study } \\
\text { data required }\end{array}$ \\
\hline Braille code & $\begin{array}{l}\text { Braille code is not } \\
\text { required on labelling }\end{array}$ & $\begin{array}{l}\text { Braille code is required on } \\
\text { labelling }\end{array}$ & $\begin{array}{l}\text { Braille code is not } \\
\text { required } \\
\text { labelling }\end{array}$ \\
\hline $\begin{array}{l}\text { Post-approval } \\
\text { changes }\end{array}$ & $\begin{array}{l}\text { Post-approval changes } \\
\text { in the approved drug: } \\
\text { - Minor changes } \\
\text { - Moderate changes } \\
\text { - Major changes }\end{array}$ & $\begin{array}{l}\text { Post-variation in the } \\
\text { approved drug: } \\
\text { - Type IA Variation } \\
\text { - Type IB Variation } \\
\text { - Type II Variation }\end{array}$ & $\begin{array}{lr}\begin{array}{l}\text { Post } \\
\text { changes: }\end{array} & \text { approval } \\
\text { Major } & \text { quality } \\
\text { changes } & \\
\begin{array}{l}\text { Moderate } \\
\text { changes }\end{array} & \text { quality } \\
\end{array}$ \\
\hline
\end{tabular}

Table 2: Administrative Requirements

\begin{tabular}{|c|c|c|c|}
\hline Requirements & US & EU & INDIA \\
\hline Application & ANDA / NDA & MAA & MAA \\
\hline $\begin{array}{c}\text { Debarment } \\
\text { classification }\end{array}$ & Required & Not Required & 1 \\
\hline $\begin{array}{c}\text { Number of } \\
\text { copies }\end{array}$ & 3 & 1 & $12-18$ Months \\
\hline $\begin{array}{c}\text { Approval } \\
\text { Timeline }\end{array}$ & $\sim 18$ Months & $\sim 12$ Months & 50,000 INR \\
\hline Fees & $\begin{array}{c}\text { Under \$2 million-NDA } \\
\text { Application } \\
\text { \$51,520 - ANDA } \\
\text { Application }\end{array}$ & $\begin{array}{c}\text { National } \\
\text { fee (including hybrid } \\
\text { applications): } \\
£ 103,059 \\
\text { Decentralised } \\
\text { procedure where UK } \\
\text { is CMS: } £ 99,507\end{array}$ & Paper \\
\hline Presentation & eCTD \& Paper & eCTD & \\
\hline
\end{tabular}


Table 3: Finished Product Control Requirements

\begin{tabular}{|c|c|c|c|}
\hline Requirements & US & EU & INDIA \\
\hline Justification & ICH Q6A & ICH Q6A & ICH Q6A \\
\hline Assay & $90-100 \%$ & $95-105 \%$ & $90-110 \%$ \\
\hline Disintegration & Not Required & Required & Required \\
\hline $\begin{array}{c}\text { Colour } \\
\text { Identification }\end{array}$ & Not Required & Required & Required \\
\hline Water Content & Required & Not Required & Required \\
\hline
\end{tabular}

Table 4: Manufacturing \& Control Requirements

\begin{tabular}{|c|c|c|c|}
\hline Requirements & US & $\mathbf{E U}$ & INDIA \\
\hline $\begin{array}{c}\text { Number of } \\
\text { batches }\end{array}$ & 1 & 3 & 1 \\
\hline Packaging & $\begin{array}{l}\text { A minimum of } 1,00,000 \\
\text { Units }\end{array}$ & Not Required & Not addressed \\
\hline $\begin{array}{l}\text { Process } \\
\text { Validation } \\
\end{array}$ & $\begin{array}{c}\text { Not required at the time } \\
\text { of submission }\end{array}$ & Required & Required \\
\hline Batch Size & $\begin{array}{l}1 \text { pilot scale or } \\
\text { minimum of } 1 \text { lakh units } \\
\text { whichever is higher. }\end{array}$ & $\begin{array}{l}2 \text { pilot scale plus } 1 \text { lab batch or } \\
\text { minimum of } 1 \text { lakh units } \\
\text { whichever is higher. }\end{array}$ & Pilot scale batch \\
\hline
\end{tabular}

Table 5: Stability Requirements

\begin{tabular}{|c|c|c|c|}
\hline Requirements & US & $\mathbf{E U}$ & INDIA \\
\hline $\begin{array}{l}\text { Number of } \\
\text { batches }\end{array}$ & $\begin{array}{l}3 \text { Pilot Batch or } 2 \text { Pilot } \\
\text { Batch \& } 1 \text { Small scale }\end{array}$ & $\begin{array}{l}2 \text { Pilot Scale (If API Stable) } \\
3 \text { Primary Batches } \\
\text { (If API unstable) }\end{array}$ & $\begin{array}{c}2 \text { Pilot Scale/Production } \\
\text { scale(If API Stable) } \\
3 \text { Primary Batches (If API } \\
\text { unstable) }\end{array}$ \\
\hline $\begin{array}{l}\text { Condition: Long } \\
\text { term stability, } \\
\text { Accelerated } \\
\text { stability, }\end{array}$ & $\begin{array}{l}\text { Long term: } \\
25^{\circ} \mathrm{C} / 60 \% \mathrm{RH} \\
\text { Accelerated: } \\
40^{\circ} \mathrm{C} / 75 \% \mathrm{RH}(0,3,6 \\
\text { months }) \text {; Intermediate: } \\
30^{\circ} \mathrm{C} / 65 \% \mathrm{RH}\end{array}$ & $\begin{array}{l}\text { Long term: } 25^{\circ} \mathrm{C} / 60 \% \mathrm{RH} \\
\text { Accelerated: } \\
40^{\circ} \mathrm{C} / 75 \% \mathrm{RH}(0,3,6 \text { months }) \\
\text { Intermediate: } 30^{\circ} \mathrm{C} / 65 \% \mathrm{RH}\end{array}$ & $\begin{array}{l}\text { Long term: } 30^{\circ} \mathrm{C} / 70 \% \mathrm{RH} \\
\text { Accelerated: } 40^{\circ} \mathrm{C} / 75 \% \mathrm{RH} \\
(0,3,6 \text { months })\end{array}$ \\
\hline $\begin{array}{l}\text { Minimum time } \\
\text { period at } \\
\text { Submission } \\
\end{array}$ & $\begin{array}{l}6 \text { Months Accelerate \& } \\
6 \text { Months long term }\end{array}$ & $\begin{array}{l}6 \text { Months Accelerate \& } 6 \\
\text { Months long term }\end{array}$ & $\begin{array}{c}6 \text { Months Accelerate \& } 6 \\
\text { Months long term }\end{array}$ \\
\hline $\begin{array}{l}\text { Container } \\
\text { orientation }\end{array}$ & Inverted \& Upright & Do not address & upright and inverted \\
\hline Clause & $21 \mathrm{CFR}$ part $210 \& 211$ & $\begin{array}{c}\text { Volume } 4 \text { EU Guidelines for } \\
\text { medicinal products }\end{array}$ & ICH Q1F \\
\hline QP Certification & Not Required & Required & Required \\
\hline
\end{tabular}


Table 6: Bioequivalence Requirements

\begin{tabular}{|c|c|c|c|}
\hline Requirements & US & EU & INDIA \\
\hline $\begin{array}{c}\text { CRO } \\
\text { (Audits) }\end{array}$ & $\begin{array}{c}\text { Audited by } \\
\text { FDA }\end{array}$ & $\begin{array}{c}\text { Audited by } \\
\text { MHRA }\end{array}$ & CDSCO \\
\hline $\begin{array}{c}\text { Reserve } \\
\text { Sample }\end{array}$ & $\begin{array}{c}5 \text { times the sample } \\
\text { required for analysis }\end{array}$ & No such requirement & - \\
\hline Fasted / Fed & $\begin{array}{c}\text { Must be as per OGD } \\
\text { recommendation }\end{array}$ & $\begin{array}{c}\text { No such } \\
\text { requirement }\end{array}$ & $\begin{array}{c}\text { As CDSCO } \\
\text { recommendation }\end{array}$ \\
\hline $\begin{array}{c}\text { Retention of } \\
\text { samples }\end{array}$ & $\begin{array}{c}5 \text { years from date of } \\
\text { filing the application }\end{array}$ & $\begin{array}{c}\text { No such requirement } \\
\text { BE study for } \\
\text { generic drugs }\end{array}$ & $\begin{array}{c}\text { Against US RLD in any } \\
\text { country. To refer 'BE } \\
\text { recommendations' in } \\
\text { the application filing }\end{array}$ \\
\hline FDA site for guidance. & $\begin{array}{c}\text { Against EU reference } \\
\text { product (ERP) in any } \\
\text { country }\end{array}$ & $\begin{array}{c}\text { Against US/EU/Australia } \\
\text { RLD in any country except } \\
\text { Thailand, where BE to be } \\
\text { done locally against local } \\
\text { reference product. }\end{array}$ \\
\hline
\end{tabular}

\section{Conclusion:}

The Drug approvals in the US, Europe \& India are the most demanding in the world. The primary purpose of the rules governing medicinal products in US, Europe \& India is to safeguard public health. It is the role of public regulatory authorities to ensure that pharmaceutical companies comply with regulations. There are legislations that require drugs to be developed, tested, trailed, and manufactured in accordance to the guidelines so that they are safe and patient's well - being is protected.

\section{References:}

1. Rick NG. Drugs from discovery to approval. 2nd ed. John Wiley \& Sons, Inc.; 2008. p. 201202.

2. IRA RB, Robert PM. The Pharmaceutical Regulatory Process. 2nd ed. Informa healthcare; 2008. p. 45.

3. Rick NG. Drugs from discovery to approval. 2nd ed. John Wiley \& Sons, Inc.; 2008. p. 203210.
4. IRA RB, Robert PM. The Pharmaceutical Regulatory Process. 2nd ed. Informa healthcare; 2008. p. 46-48.

5. Rick NG. Drugs from discovery to approval. 2nd ed. John Wiley \& Sons, Inc.; 2008. p. 212220.

6. IRA RB, Robert PM. The Pharmaceutical Regulatory Process. 2nd ed. Informa healthcare; 2008. p. 49-51.

7. Clinical Trial \& Global Clinical Trial [Internet].[cited 2014 January].Available from: http://cdsco.nic.in/clinical_trial.htm.

8. The New Drug Approval Process [Internet].[cited 2014 January].Available from: http://www.fda.gov/cder/handbook.

9. CDER Guidance: IND application process (interactive session) [Internet].[cited 2014 January].Available from: www.fda.gov/cder/regulatory/applications/ind_ page_1.htm.

10. Guidance for industry on preparation of common technical document for import/ manufacture and marketing approval of new drugs for human use. (NEW DRUG APPLICATION-NDA) [Internet].[cited 2014 January].Available http://cdsco.nic.in/CTD_Guidance\%20Final.pdf. 